\section{RMD Open}

Rheumatic \&

Musculoskeletal Diseases

\title{
Evolution of psoriatic arthritis study patient population characteristics in the era of biological treatments
}

\author{
Ann-Sophie Vandendorpe, ${ }^{1}$ Kurt de Vlam, ${ }^{1,2}$ Rik Lories ${ }^{1,2}$
}

To cite: Vandendorpe A-S, de Vlam K, Lories R. Evolution of psoriatic arthritis study patient population characteristics in the era of biological treatments. RMD Open 2019:5:e000779. doi:10.1136/ rmdopen-2018-000779

- Prepublication history for this paper is available online. To view these files, please visit the journal online (http://dx.doi. org/10.1136/rmdopen-2018000779).

Received 27 July 2018 Revised 29 November 2018 Accepted 17 December 2018

A Check for updates

C) Author(s) (or their employer(s)) 2019. Re-use permitted under CC BY-NC. No commercial re-use. See rights and permissions. Published by BMJ.

${ }^{1}$ Department of Development and Regeneration, Skeletal Biology and Engineering Research Center, KU Leuven, Leuven, Belgium

${ }^{2}$ Division of Rheumatology, University Hospitals Leuven, Leuven, Belgium

Correspondence to Professor Rik Lories; rik.lories@uz.kuleuven.be

\section{ABSTRACT}

Objectives Psoriatic arthritis is a chronic inflammatory disease that affects the musculoskeletal system. It can include arthritis, spondylitis, dactylitis and enthesitis, and is strongly associated with the presence of psoriasis. The introduction of biological therapies as a treatment option has brought a significant improvement in disease control for patients with psoriatic arthritis. Here, we aimed to detect emerging differences in demographic and clinical characteristics of the psoriatic arthritis patient study population since the introduction of biologicals. We hypothesised that evolving views on control of disease activity and increased experience in the management of psoriatic arthritis have affected the patient population considered for clinical trials and that this may serve as a proxy for changes in clinical practice.

Methods We systematically searched for and selected 12 phase II and phase III trials and divided them into three treatment periods based on different time periods and working mechanisms of the particular biologicals. We made a selection of patient and disease parameters for which data were available in all three periods, calculated those data per period and looked for statistically significant differences between the treatment periods.

Results Statistical analysis showed significant differences in patient characteristics, disease characteristics, disease activity, disease effects and use of prior treatments between the patient populations of the three periods. Conclusion This study shows a clear evolution of the patient population considered for clinical trials since the introduction of biologicals. Further research is needed to see if those changes can be detected in the daily clinical practice.

\section{INTRODUCTION}

Psoriatic arthritis (PsA) is a chronic inflammatory disease that can affect both the appendicular and the axial skeleton. The clinical manifestations include arthritis, spondylitis, enthesitis and dactylitis. ${ }^{1}$ Clinical enthesitis most commonly involves the plantar fascia and Achilles' tendon and is observed in $30 \%-50 \%$ of patients with PsA. Dactylitis, often associated with severe disease, is present in $40 \%-50 \%$ of patients. ${ }^{1}$ PsA is strongly associated with the skin disorder psoriasis.

\section{Key messages}

What is already known about this subject?

- We hypothesised that changing views on the disease and experience with biologicals can affect the patient population considered for clinical trials and consider this a proxy for clinical practice.

- Biological treatments have transformed the management of psoriatic arthritis. Rheumatologists have gained substantial experience with these drugs, possibly affecting the target population of patients in which they consider their use.

What does this study add?

- By reanalysing literature data, we demonstrate that patients considered for clinical trials with new biologicals differ from the population in the original trials. Over time, patients become older and had overall less objective disease activity whereas patient-reported outcomes suggest more impact of the disease.

How might this impact on clinical practice?

- We confirmed our hypothesis that more patients are considered for biological therapy than earlier in the initial phase of these treatments. Despite shorter disease duration and lower objective measurements of inflammation, the burden of disease remains very high.

- This appears to imply that the physician's good experience with new treatments facilitates the decision-making process but also may warn against direct comparisons of clinical trial data originating from different time periods.

Effectively, up to $40 \%$ of patients with psoriasis may develop some form of psoriatic arthritis during their lifetime. Skin disease usually precedes joint disease but the two can also appear simultaneously, or joint disease may develop long before the skin is affected. In rare cases, skin or nail psoriasis may never develop. PsA has an estimated prevalence of $0.3 \%-1.0 \%$ in the general population. Long time considered a relatively benign form of arthritis, epidemiological data have clearly 
identified psoriatic arthritis as a potentially severe joint disease strongly associated with structural damage and loss of joint function, resulting in increased morbidity and even mortality. In addition to the impact of joint and skin disease, many patients with PsA also have comorbidities such as obesity, metabolic syndrome and depression.

Treatment strategies for PsA have rapidly evolved over the last 15 years. Until the introduction of biological therapies, therapeutic options were largely limited to the use of non-steroidal anti-inflammatory drugs (NSAIDs), chemical immune-modulators such as methotrexate (MTX), sulfasalazine and leflunomide, and the intermittent or chronic use of glucocorticoids (GC). The introduction of anti-tumour necrosis factor (TNF) antibodies or soluble receptors has dramatically changed the management of the disease and the perspectives of the patients as these interventions have a considerable impact on signs and symptoms, as well as structural damage and associated loss of function. ${ }^{1}$ Since then, therapeutic options are increasing steadily with the current availability of five different anti-TNF drugs, the more recent introduction of other biologicals targeting interleukin-17 (IL-17), the common p40 subunit of IL-12 and IL-23, and a small molecule phosphodiesterase- 4 inhibitor. Other strategies in clinical development are targeting the p19 unit of IL-23 and the JAK/STAT kinase pathways. ${ }^{2-4}$

Both the availability of new and different treatment options as well as the increased experience over time in the management of patients with PsA with such drugs may have a profound impact on daily clinical practice. Increased attention towards PsA has resulted in the availability of these new drugs and also boosted research into patient outcomes or therapeutic strategies, and raised the bar for control of disease activity. In this context, it is unclear how the changing landscape and the experience in managing PsA with biologicals has affected the patient population considered for such trial interventions. Here, we aimed to study how PsA patient populations in pivotal clinical trials evolved during the increased uptake and use of biologicals in daily clinical practice.

\section{METHODS}

\section{Study selection}

PubMed was used for a literature search to identify the pre-marketing phase II and phase III double-blind randomised clinical trials for the drugs of interest. Search terms were "drug name" AND "psoriatic arthritis" with filters "clinical trial" and "English". Twelve articles fulfilling our criteria were finally selected (table 1) (two for etanercept, two for infliximab, one for adalimumab, one for golimumab, one for certolizumab pegol, two for ustekinumab, two for secukinumab and one for apremilast). Our final list was compared with an overview of psoriatic arthritis clinical trials as published by Ogdie and Coates. ${ }^{5}$ Three periods for novel treatments were defined. The first period contains the three initial TNF inhibitors: etanercept, infliximab and adalimumab. The second period consists of two more recent TNF inhibitors: golimumab and certolizumab pegol. The drugs in the third period have different modes of action and were most recently studied: ustekinumab, secukinumab and apremilast. The phase II trial for apremilast, ${ }^{6}$ published in 2012, was not included as it did not align timewise with the other trials included in the third period. Only drugs with European Medicine Agents approval by November 2017 were included. Table 1 also lists key inclusion criteria that could affect patient characteristics.

\section{Data collection}

Published tables with the baseline demographic and clinical characteristics of study population from the individual studies were used. For inclusion of a specific parameter, it had to be present in at least one study of each period. An exception to this rule was made for the 'number of patients with prior anti-TNF therapy', a variable that was only present in studies from the second and third periods. Parameters were defined in different categories: patient characteristics (gender, age, race, weight), disease characteristics (duration of PsA, presence of dactylitis, presence of enthesitis, psoriasis body surface area (BSA)), disease activity parameters (swollen joint count (SJC), tender joint count (TJC), C reactive protein (CRP) level, Visual Analogue Scale (VAS) of disease activity and pain, Disease Activity Score (DAS), Psoriasis Area Severity Index (PASI) score), disease effects (Total Sharp Score (TSS), Health Assessment Questionnaire Disability Index (HAQ-DI) score) and prior treatments (anti-TNF therapy, baseline use of MTX, baseline use of oral GC, baseline use of NSAIDs).

\section{Data quantification and analysis}

For the continuous data, we calculated a weighted mean and SD per period. Data not available in the form of mean $\pm \mathrm{SD}$ in the original studies were therefore not included (see table 2). For the discrete data, we summed up the patients meeting the criterion from all the studies in a given period and calculated a percentage per that specified period (see table 3). We used the RStudio program software for statistical analysis of our data. For the normally divided data, we used the ANOVA test for a group analysis to find significant differences between the time periods. For the discrete data, we used the ${ }^{2}$ test. Table 4 gives an overview of the results of our statistical analysis.

\section{RESULTS}

Period 1 included 882 patients in total (265 for etanercept, 304 for infliximab and 313 for adalimumab); period 2, 814 patients (405 for golimumab and 409 for certolizumab); and period 3, 2434 patients (927 for ustekinumab, 1003 for secukinumab and 504 for apremilast).

\section{Patient characteristics}

For gender, there was a statistically significant difference between period 1 and period 3, with a lower percentage of 
Table 1 Phase II/phase III trials included for analysis

\begin{tabular}{|c|c|c|c|c|c|c|c|}
\hline Title & Author & $\begin{array}{l}\text { Year of } \\
\text { publication }\end{array}$ & $\begin{array}{l}\text { Phase II/ } \\
\text { phase III } \\
\text { trial }\end{array}$ & Product & $\begin{array}{l}\text { Tender and } \\
\text { swollen joints } \\
\text { for inclusion }\end{array}$ & $\begin{array}{l}\text { Psoriasis } \\
\text { criteria for } \\
\text { inclusion }\end{array}$ & Reference \\
\hline $\begin{array}{l}\text { Etanercept in the treatment of psoriatic } \\
\text { arthritis and psoriasis: a randomised } \\
\text { trial }\end{array}$ & $\begin{array}{l}\text { Mease PJ } \\
\text { et al }\end{array}$ & 2000 & Phase II & $\begin{array}{l}\text { Etanercept } \\
\text { (E1) }\end{array}$ & $>3$ & Not required & 13 \\
\hline $\begin{array}{l}\text { Etanercept treatment of psoriatic } \\
\text { arthritis: safety, efficacy, and effect on } \\
\text { disease progression }\end{array}$ & $\begin{array}{l}\text { Mease PJ } \\
\text { et al }\end{array}$ & 2004 & Phase III & $\begin{array}{l}\text { Etanercept } \\
\text { (E2) }\end{array}$ & $>3$ & Not required & 14 \\
\hline $\begin{array}{l}\text { Sustained benefits of infliximab } \\
\text { therapy for dermatologic and articular } \\
\text { manifestations of psoriatic arthritis: } \\
\text { results from the infliximab multinational } \\
\text { psoriatic arthritis controlled trial } \\
\text { (IMPACT) }\end{array}$ & $\begin{array}{l}\text { Antoni CE } \\
\text { et al }\end{array}$ & 2005 & Phase III & Infliximab (I1) & $\begin{array}{l}>5+\text { elevated } \\
\text { CRP (15 } \\
\mathrm{mg} / \mathrm{L}) \text { or ESR } \\
(28 \mathrm{~mm} / \mathrm{h}) \\
\text { or morning } \\
\text { stiffness }>45 \\
\text { min }\end{array}$ & Not required & 15 \\
\hline $\begin{array}{l}\text { Infliximab improves signs and } \\
\text { symptoms of psoriatic arthritis: results } \\
\text { of the IMPACT } 2 \text { trial }\end{array}$ & $\begin{array}{l}\text { Antoni CE } \\
\text { et al }\end{array}$ & 2005 & Phase III & Infliximab (I2) & $\begin{array}{l}>5+\text { elevated } \\
\text { CRP }(15 \mathrm{mg} / \mathrm{L}) \\
\text { or morning } \\
\text { stiffness }>45 \\
\text { min }\end{array}$ & $\begin{array}{l}\text { Psoriasis } \\
\text { lesion }>2 \mathrm{~cm}\end{array}$ & 16 \\
\hline $\begin{array}{l}\text { Adalimumab for the treatment of } \\
\text { patients with moderately to severely } \\
\text { active psoriatic arthritis: results of a } \\
\text { double-blind, randomised, placebo- } \\
\text { controlled trial }\end{array}$ & $\begin{array}{l}\text { Mease PJ } \\
\text { et al }\end{array}$ & 2005 & Phase III & Adalimumab & $>3$ & $\begin{array}{l}\text { Active or } \\
\text { documented } \\
\text { history of } \\
\text { psoriasis }\end{array}$ & 17 \\
\hline $\begin{array}{l}\text { Golimumab, a new human tumour } \\
\text { necrosis factor alpha antibody, }\end{array}$ & $\begin{array}{l}\text { Kavanaugh } \\
\text { A et al }\end{array}$ & 2009 & Phase III & Golimumab & $>3$ & $\begin{array}{l}\text { Psoriasis } \\
\text { lesion }>2 \mathrm{~cm}\end{array}$ & 18 \\
\hline
\end{tabular}

A et al

lesion $>2 \mathrm{~cm}$

administered every 4 weeks as a

subcutaneous injection in psoriatic

arthritis: twenty-four week efficacy and

safety results of a randomised, placebocontrolled study

\begin{tabular}{|c|c|c|c|c|c|c|c|}
\hline $\begin{array}{l}\text { Effect of certolizumab pegol on signs } \\
\text { and symptoms in patients with psoriatic } \\
\text { arthritis: } 24 \text { week results of a phase } \\
3 \text { double-blind randomised placebo- } \\
\text { controlled study (RAPID-PsA) }\end{array}$ & $\begin{array}{l}\text { Mease PJ } \\
\text { et al }\end{array}$ & 2014 & Phase III & Certolizumab & $\begin{array}{l}>3+\text { elevated } \\
\text { CRP }(7.5 \mathrm{mg} / \mathrm{L}) \\
\text { or ESR }(28 \\
\mathrm{mm} / \mathrm{h})\end{array}$ & $\begin{array}{l}\text { Active or } \\
\text { documented } \\
\text { history of } \\
\text { psoriasis }\end{array}$ & 19 \\
\hline $\begin{array}{l}\text { Efficacy and safety of ustekinumab in } \\
\text { patients with active psoriatic arthritis: } 1 \\
\text { year results of the phase } 3 \text {, multicentre, } \\
\text { double-blind, placebo-controlled } \\
\text { PSUMMIT } 1 \text { trial }\end{array}$ & $\begin{array}{l}\text { Mclnnes IB } \\
\text { et al }\end{array}$ & 2013 & Phase II & $\begin{array}{l}\text { Ustekinumab } \\
\text { (U1) }\end{array}$ & $\begin{array}{l}>5+\text { CRP }(3.0 \\
\mathrm{mg} / \mathrm{L})\end{array}$ & $\begin{array}{l}\text { Active or } \\
\text { documented } \\
\text { history of } \\
\text { psoriasis }\end{array}$ & 20 \\
\hline $\begin{array}{l}\text { Efficacy and safety of the anti-IL-12/23 } \\
\text { p40 monoclonal antibody, ustekinumab, } \\
\text { in patients with active psoriatic arthritis } \\
\text { despite conventional non-biological and } \\
\text { biological anti-tumour necrosis factor } \\
\text { therapy: } 6 \text { month and } 1 \text { year results } \\
\text { of the phase } 3 \text {, multicentre, double- } \\
\text { blind, placebo-controlled, randomised } \\
\text { PSUMMIT } 2 \text { trial }\end{array}$ & $\begin{array}{l}\text { Ritchlin C } \\
\text { et al }\end{array}$ & 2014 & Phase III & $\begin{array}{l}\text { Ustekinumab } \\
\text { (U2) }\end{array}$ & $\begin{array}{l}>5+\mathrm{CRP}(6.0 \text {, } \\
\text { in trial adapted } \\
\text { to } 3.0 \mathrm{mg} / \mathrm{L})\end{array}$ & $\begin{array}{l}\text { Active or } \\
\text { documented } \\
\text { history of } \\
\text { psoriasis }\end{array}$ & 21 \\
\hline $\begin{array}{l}\text { Secukinumab, a human anti-interleukin- } \\
17 \mathrm{~A} \text { monoclonal antibody, in patients } \\
\text { with psoriatic arthritis (FUTURE 2): a } \\
\text { randomised, double-blind, placebo- } \\
\text { controlled, phase } 3 \text { trial }\end{array}$ & $\begin{array}{l}\text { Mclnnes IB } \\
\text { et al }\end{array}$ & 2015 & Phase III & $\begin{array}{l}\text { Secukinumab } \\
\text { (S2) }\end{array}$ & $>3$ & Not required & 23 \\
\hline $\begin{array}{l}\text { Treatment of psoriatic arthritis in } \\
\text { a phase } 3 \text { randomised, placebo- } \\
\text { controlled trial with apremilast, an oral } \\
\text { phosphodiesterase } 4 \text { inhibitor }\end{array}$ & $\begin{array}{l}\text { Kavanaugh } \\
\text { A et al }\end{array}$ & 2014 & Phase III & Apremilast & $>3$ & Not required & 24 \\
\hline
\end{tabular}

CRP, C reactive protein; ESR, erythrocyte sedimentation rate. 
Table 2 Presence of parameter data for each study in a treatment period

\begin{tabular}{|c|c|c|c|c|c|c|c|c|c|c|c|c|}
\hline \multirow[b]{2}{*}{ Parameter } & \multicolumn{5}{|c|}{ Period 1} & \multicolumn{2}{|c|}{ Period 2} & \multicolumn{5}{|c|}{ Period 3} \\
\hline & ETN1 & ETN2 & IFX1 & IFX2 & ADA & GOL & CZP & USK1 & USK2 & SEC1 & SEC2 & APR \\
\hline \multicolumn{13}{|l|}{ Patient characteristics } \\
\hline Male patients (\%) & Yes & Yes & Yes & Yes & Yes & Yes & Yes & Yes & Yes & Yes & Yes & Yes \\
\hline Age & No & Yes & Yes & Yes & Yes & Yes & Yes & No & No & Yes & Yes & Yes \\
\hline Caucasian patients (\%) & Yes & Yes & No & No & Yes & Yes & Yes & No & No & Yes & Yes & Yes \\
\hline Weight & No & No & No & No & Yes & No & Yes & No & No & Yes & Yes & Yes \\
\hline \multicolumn{13}{|l|}{ Disease characteristics } \\
\hline Duration of PsA & No & Yes & Yes & Yes & Yes & Yes & Yes & No & No & No & No & Yes \\
\hline Patients with dactylitis (\%) & No & No & Yes & Yes & No & Yes & Yes & Yes & Yes & Yes & Yes & Yes \\
\hline Patients with enthesitis (\%) & No & No & Yes & Yes & No & Yes & Yes & Yes & Yes & Yes & Yes & Yes \\
\hline Patients with BSA $\geq 3 \%$ (\%) & Yes & No & No & Yes & Yes & Yes & Yes & Yes & Yes & Yes & Yes & Yes \\
\hline \multicolumn{13}{|l|}{ Disease activity } \\
\hline SJC & NO & NO & YES & YES & YES & YES & YES & $\mathrm{NO}$ & $\mathrm{NO}$ & YES & YES & YES \\
\hline TJC & NO & NO & YES & YES & YES & YES & YES & NO & NO & YES & YES & YES \\
\hline CRP level & NO & NO & YES & YES & YES & YES & NO & NO & NO & NO & NO & YES \\
\hline $\begin{array}{l}\text { Physician's global assessment } \\
\text { of disease activity (VAS) }\end{array}$ & NO & NO & YES & YES & YES & NO & YES & NO & NO & YES & YES & YES \\
\hline $\begin{array}{l}\text { Patient's global assessment of } \\
\text { disease activity (VAS) }\end{array}$ & NO & NO & YES & YES & YES & NO & YES & NO & NO & YES & YES & YES \\
\hline $\begin{array}{l}\text { Patient's global assessment of } \\
\text { pain (VAS) }\end{array}$ & NO & NO & YES & YES & YES & NO & YES & NO & NO & YES & YES & YES \\
\hline DAS & NO & NO & YES & NO & NO & YES & $\mathrm{NO}$ & NO & NO & YES & YES & YES \\
\hline PASI & NO & NO & NO & YES & YES & YES & NO & NO & NO & YES & YES & YES \\
\hline \multicolumn{13}{|l|}{ Disease effects } \\
\hline TSS & NO & YES & NO & NO & YES & NO & YES & NO & NO & YES & NO & NO \\
\hline HAQ-DI score & $\mathrm{NO}$ & NO & YES & YES & YES & $\mathrm{NO}$ & YES & $\mathrm{NO}$ & $\mathrm{NO}$ & YES & YES & YES \\
\hline \multicolumn{13}{|l|}{ Prior treatments } \\
\hline $\begin{array}{l}\text { Patients with prior anti-TNF } \\
\text { therapy }(\%)\end{array}$ & NO & NO & NO & $\mathrm{NO}$ & $\mathrm{NO}$ & NO & YES & NO & NO & YES & YES & YES \\
\hline $\begin{array}{l}\text { Patients with baseline use of } \\
\operatorname{MTX}(\%)\end{array}$ & YES & YES & NO & YES & YES & YES & YES & YES & YES & YES & YES & YES \\
\hline $\begin{array}{l}\text { Patients with baseline use of } \\
\text { oral CS (\%) }\end{array}$ & YES & YES & NO & YES & $\mathrm{NO}$ & YES & $\mathrm{NO}$ & YES & YES & YES & YES & YES \\
\hline $\begin{array}{l}\text { Patients with baseline use of } \\
\text { NSAIDs (\%) }\end{array}$ & YES & YES & NO & YES & NO & YES & NO & YES & YES & NO & NO & YES \\
\hline
\end{tabular}

ADA, adalimumab; APR, apremilast; BSA, body surface area; CRP, C reactive protein; CS, corticosteroid; CZP, certolizumab pegol; DAS, Disease Activity Score; ETN, etanercept; GOL, golimumab; HAQ-DI, Health Assessment Questionnaire Disability Index; IFX, infliximab; MTX, methotrexate; NSAID, non-steroidal anti-inflammatory drug; PASI, Psoriasis Area Severity Index; PsA, psoriatic arthritis; SEC, secukinumab; SJC, swollen joint count;; TJC, tender joint count; TNF, tumour necrosis factor; TSS, Total Sharp Score; USK, ustekinumab; VAS, Visual Analogue Scale.

men in period 3 (49.1\% of the population, compared with $56.1 \%$ in period 1 ). The evolution between periods 1 and 2 and between periods 2 and 3 was too small to be significant.

Patients recruited in the third period of clinical trials were significantly older than the patients in period 1 $(+1.54$ years, $95 \%$ CI 0.24 to 2.84$)$ and period $2(+1.93$ years, $95 \%$ CI 0.75 to 3.11$)$. There was no significant age difference between the patients in periods 1 and 2 .
Of note, mean age and SD for period 1 was calculated for 617 patients instead of 882 because in one etanercept study median and range were used to represent the data and in the other etanercept study only mean age without SD was presented. Likwise in period 3, data for ustekinumab were represented in the form of median and range, so the mean age and SD were calculated for 1507 instead of 2434 patients. 
Table 3 Data calculated per time period

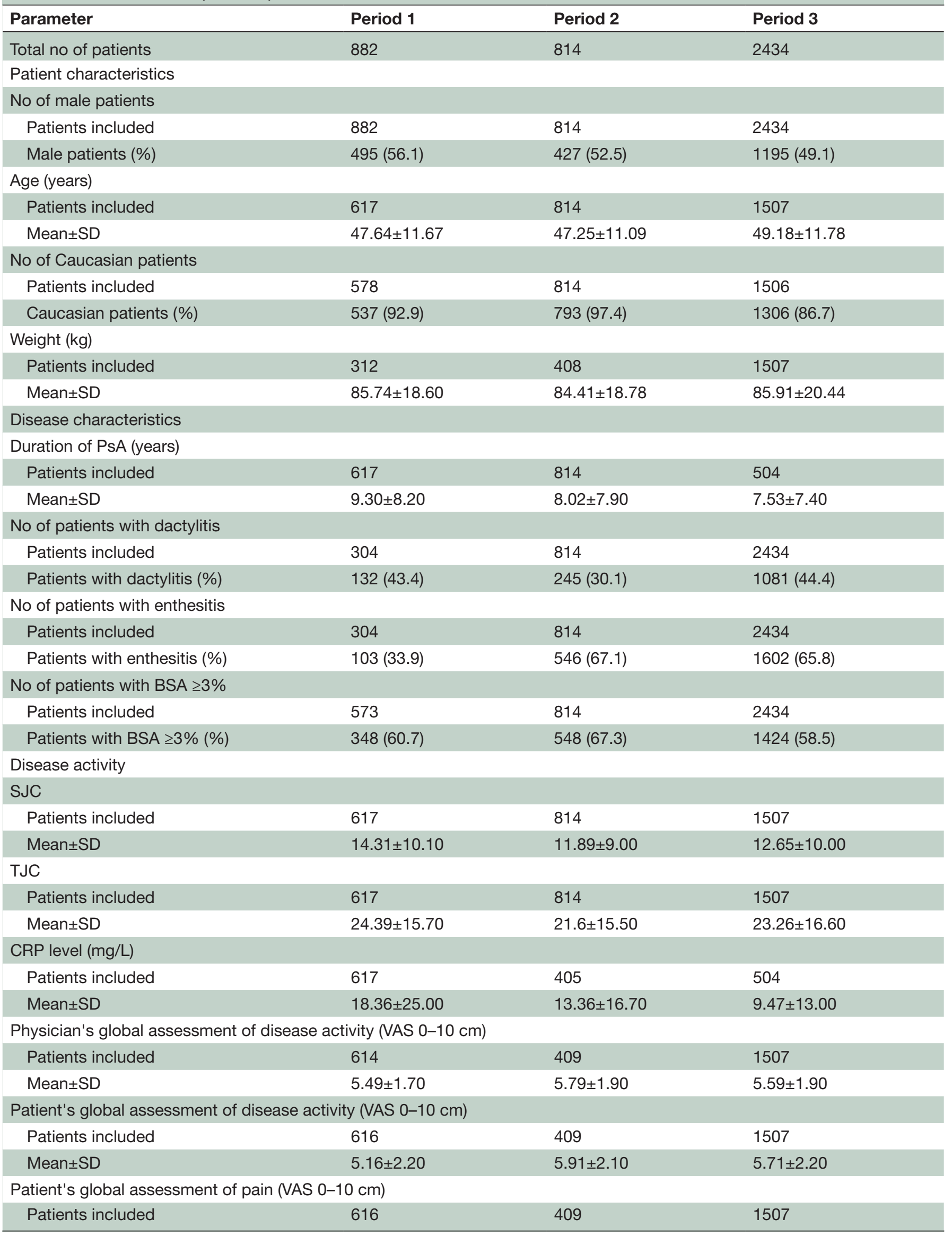




\begin{tabular}{|c|c|c|c|}
\hline Parameter & Period 1 & Period 2 & Period 3 \\
\hline Mean \pm SD & $5.32 \pm 2.20$ & $6.03 \pm 2.00$ & $5.67 \pm 2.20$ \\
\hline \multicolumn{4}{|l|}{ DAS (0-10) } \\
\hline Patients included & 104 & 405 & 1507 \\
\hline Mean \pm SD & $5.45 \pm 1.10$ & $4.34 \pm 1.00$ & $4.84 \pm 1.10$ \\
\hline \multicolumn{4}{|l|}{ PASI (0-72 scale) } \\
\hline Patients included & 308 & 296 & 744 \\
\hline Mean \pm SD & $9.47 \pm 9.30$ & $9.90 \pm 8.60$ & $12.04 \pm 10.80$ \\
\hline \multicolumn{4}{|l|}{ Disease effects } \\
\hline \multicolumn{4}{|l|}{ TSS (0-528) } \\
\hline Patients included & 311 & 409 & 606 \\
\hline Mean \pm SD & $20.84 \pm 40.90$ & $21.70 \pm 43.00$ & $23.33 \pm 50.70$ \\
\hline \multicolumn{4}{|l|}{ HAQ-DI score $(0-3)$} \\
\hline Patients included & 617 & 409 & 1507 \\
\hline Mean \pm SD & $1.06 \pm 0.70$ & $1.30 \pm 0.70$ & $1.22 \pm 0.70$ \\
\hline \multicolumn{4}{|l|}{ Prior treatments } \\
\hline \multicolumn{4}{|l|}{ No of patients with prior anti-TNF therapy } \\
\hline Patients included & No data & 409 & 1507 \\
\hline Patients with prior anti-TNF therapy (\%) & & $80(19.6)$ & $436(28.9)$ \\
\hline \multicolumn{4}{|l|}{ No of patients with baseline use of MTX } \\
\hline Patients included & 778 & 814 & 2434 \\
\hline Patients with baseline use of MTX (\%) & $363(46.7)$ & $454(55.8)$ & $1278(52.5)$ \\
\hline \multicolumn{4}{|l|}{ No of patients with baseline use of oral CS } \\
\hline Patients included & 465 & 405 & 2434 \\
\hline Patients with baseline use of oral CS (\%) & $78(16.8)$ & $65(16)$ & $375(15.4)$ \\
\hline \multicolumn{4}{|l|}{ No of patients with baseline use of NSAIDs } \\
\hline Patients included & 465 & 405 & 1431 \\
\hline Patients with baseline use of NSAIDs (\%) & $362(77.9)$ & $308(76)$ & $1037(72.5)$ \\
\hline
\end{tabular}

The number of patients considered for each parameter is mentioned under 'patients included'. For the continuous data, we calculated a weighted mean and SD per period. For the discrete data, we summed up the patients meeting the criterium from all the studies in a given period and calculated a percentage per that specified period.

BSA, body surface area; CRP, C reactive protein; CS, corticosteroid; DAS, Disease Activity Score; HAQ-DI, Health Assessment Questionnaire Disability Index; MTX, methotrexate; NSAID, non-steroidal anti-inflammatory drug; PASI, Psoriasis Area Severity Index; PsA, psoriatic arthritis; SJC, swollen joint count; TJC, tender joint count; TNF, tumour necrosis factor; TSS, Total Sharp Score; VAS, Visual Analogue Scale.

The percentage of Caucasian patients included was significantly different for all three periods. The percentage was the highest $(97.4 \%)$ in period 2 and the lowest $(86.7 \%)$ in period 3 . There were no data available for race in the infliximab studies, so in period 1, 578 patients were included. In period 3, there were no data for race in the ustekinumab studies and for one patient in one of the secukinumab studies, so the percentage of Caucasians was calculated for 1506 patients instead of 2434.

There was no statistically significant difference in mean weight between the periods. The mean weight and SD in period 1 was calculated for 312 patients because of missing data or data in the form of median and range in the etanercept and infliximab studies. In the adalimumab study, there was no weight reported for one patient.
In period 2, there were no weight data available in the golimumab study nor for one patient in the certolizumab study, so only 408 patients were included. In period 3, the data for ustekinumab were represented in the form of median and range, so the mean weight and SD were calculated for 1507 instead of 2434 patients.

\section{Disease characteristics}

The duration of psoriatic arthritis was the longest for the study populations in period 1 and was significantly shorter in period $2(-1.28$ years, $95 \% \mathrm{CI}-2.27$ to -0.29$)$ and period $3(-1.77$ years, $95 \%$ CI -2.88 to -0.66$)$. The difference in duration of PsA between period 2 and period $3(+0.49$ years, $95 \%$ CI -1.54 to 0.56$)$ was not statistically significant. Duration of PsA was calculated for 617 patients in period 1 and for 504 patients in period 3. 
Table 4 Statistical analysis: significant differences between the periods

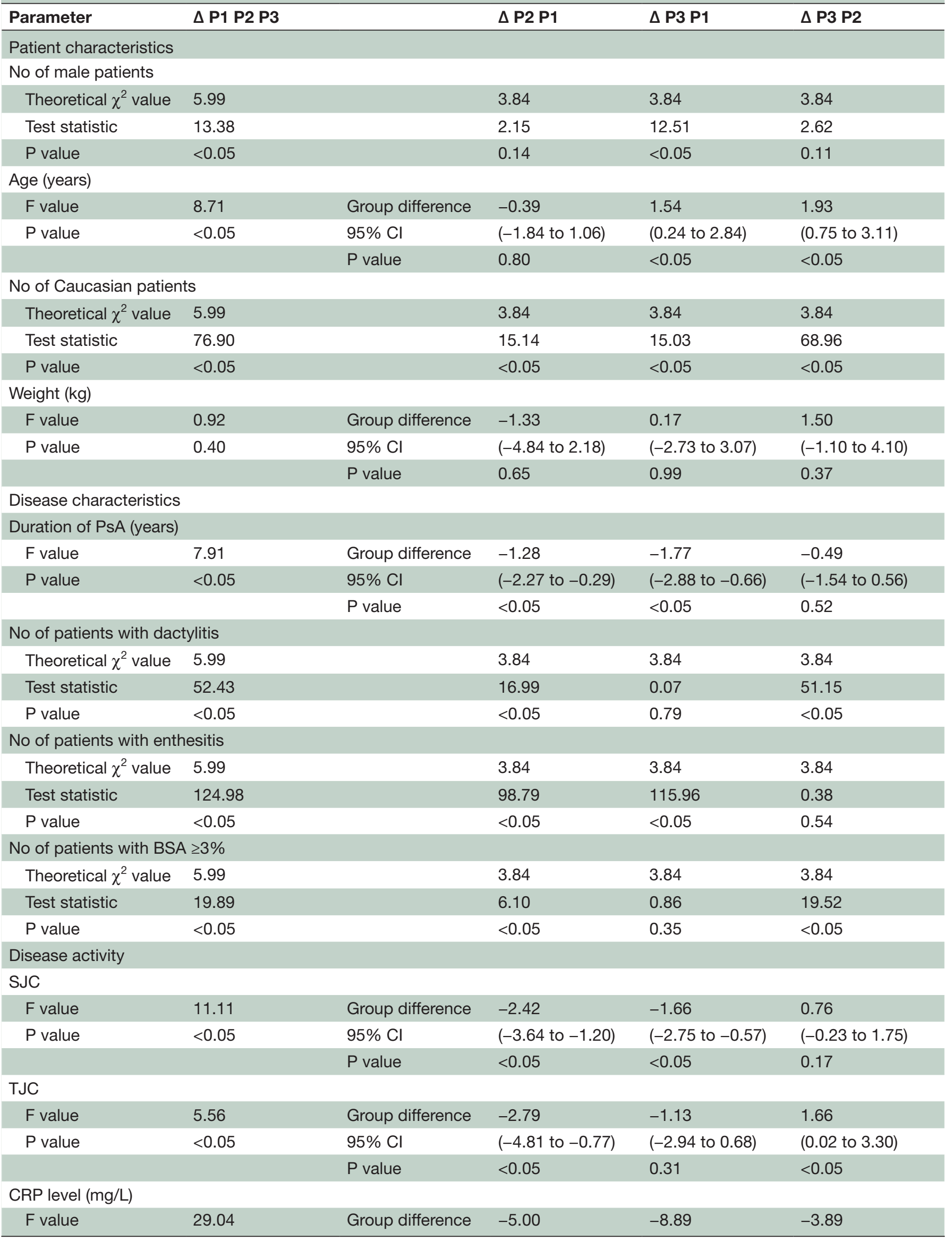




\begin{tabular}{|c|c|c|c|c|c|}
\hline Parameter & $\Delta$ P1 P2 P3 & & $\Delta \mathrm{P} 2 \mathrm{P1}$ & $\Delta \mathrm{P3}$ P1 & $\Delta$ P3 P2 \\
\hline \multirow[t]{2}{*}{$P$ value } & $<0.05$ & $95 \% \mathrm{Cl}$ & $(-7.93$ to -2.07$)$ & $(-11.65$ to -6.13$)$ & $(-6.95$ to -0.83$)$ \\
\hline & & $P$ value & $<0.05$ & $<0.05$ & $<0.05$ \\
\hline \multicolumn{6}{|c|}{ Physician's global assessment of disease activity (VAS 0-10 cm) } \\
\hline F value & 3.25 & Group difference & 0.30 & 0.10 & -0.20 \\
\hline \multirow[t]{2}{*}{$P$ value } & $<0.05$ & $95 \% \mathrm{Cl}$ & (0.02 to 0.58$)$ & $(-0.11$ to 0.31$)$ & $(-0.44$ to 0.04$)$ \\
\hline & & $P$ value & $<0.05$ & 0.50 & 0.13 \\
\hline \multicolumn{6}{|c|}{ Patient's global assessment of disease activity (VAS $0-10 \mathrm{~cm}$ ) } \\
\hline F value & 18.51 & Group difference & 0.75 & 0.55 & -0.20 \\
\hline \multirow[t]{2}{*}{$P$ value } & $<0.05$ & $95 \% \mathrm{Cl}$ & (0.42 to 1.08$)$ & (0.31 to 0.79$)$ & $(-0.49$ to 0.09$)$ \\
\hline & & $P$ value & $<0.05$ & $<0.05$ & 0.23 \\
\hline \multicolumn{6}{|c|}{ Patient's global assessment of pain (VAS 0-10 cm) } \\
\hline F value & 13.46 & Group difference & 0.71 & 0.35 & -0.36 \\
\hline \multirow[t]{2}{*}{$P$ value } & $<0.05$ & $95 \% \mathrm{Cl}$ & (0.39 to 1.03$)$ & (0.11 to 0.59$)$ & $(-0.64$ to -0.08$)$ \\
\hline & & $P$ value & $<0.05$ & $<0.05$ & $<0.05$ \\
\hline \multicolumn{6}{|l|}{ DAS $(0-10)$} \\
\hline F value & 55.81 & Group difference & -1.11 & -0.61 & 0.50 \\
\hline \multirow[t]{2}{*}{$P$ value } & $<0.05$ & $95 \% \mathrm{Cl}$ & $(-1.39$ to -0.83$)$ & $(-0.87$ to -0.35$)$ & (0.36 to 0.64$)$ \\
\hline & & $P$ value & $<0.05$ & $<0.05$ & $<0.05$ \\
\hline \multicolumn{6}{|c|}{ PASI (0-72 scale) } \\
\hline F value & 9.38 & Group difference & 0.43 & 2.57 & 2.14 \\
\hline \multirow[t]{2}{*}{$P$ value } & $<0.05$ & $95 \% \mathrm{Cl}$ & (-1.48 to 2.34$)$ & (0.98 to 4.16 ) & (0.52 to 3.76 ) \\
\hline & & $P$ value & 0.86 & $<0.05$ & $<0.05$ \\
\hline
\end{tabular}

\section{Disease effects}

TSS (0-528)

$\begin{array}{llllll}\mathrm{F} \text { value } & 0.34 & \text { Group difference } & 0.86 & 2.49 & 1.63 \\ \mathrm{P} \text { value } & 0.71 & 95 \% \mathrm{Cl} & (-7.30 \text { to } 9.02) & (-5.08 \text { to } 10.06) & (-5.31 \text { to } 8.57) \\ & & \mathrm{P} \text { value } & 0.97 & 0.72 & 0.85\end{array}$

HAQ-DI score (0-3)

$\begin{array}{llllll}\mathrm{F} \text { value } & 17.03 & \text { Group difference } & 0.24 & 0.16 & -0.08 \\ \mathrm{P} \text { value } & <0.05 & 95 \% \mathrm{Cl} & (0.14 \text { to } 0.34) & (0.08 \text { to } 0.24) & (-0.17 \text { to } 0.01) \\ & & \mathrm{P} \text { value } & <0.05 & <0.05 & 0.10\end{array}$

\section{Prior treatments}

No of patients with prior anti-TNF therapy

\begin{tabular}{|c|c|c|c|c|}
\hline Theoretical $\chi^{2}$ value & No data & No data & No data & 3.84 \\
\hline Test statistic & & & & 13.89 \\
\hline$P$ value & & & & $<0.05$ \\
\hline \multicolumn{5}{|c|}{ No of patients with baseline use of MTX } \\
\hline Theoretical $\chi^{2}$ value & 5.99 & 3.84 & 3.84 & 3.84 \\
\hline Test statistic & 13.79 & 12.87 & 7.84 & 2.49 \\
\hline$P$ value & $<0.05$ & $<0.05$ & $<0.05$ & 0.11 \\
\hline \multicolumn{5}{|c|}{ No of patients with baseline use of oral CS } \\
\hline Theoretical $\chi^{2}$ value & 5.99 & 3.84 & 3.84 & 3.84 \\
\hline Test statistic & 0.60 & 0.04 & 0.45 & 0.07 \\
\hline$P$ value & 0.74 & 0.84 & 0.5 & 0.80 \\
\hline
\end{tabular}


Table 4 Continued

\begin{tabular}{|c|c|c|c|c|}
\hline Parameter & $\triangle$ P1 P2 P3 & $\Delta \mathrm{P} 2 \mathrm{P1}$ & $\Delta$ P3 P1 & $\triangle$ P3 P2 \\
\hline \multicolumn{5}{|c|}{ No of patients with baseline use of NSAIDs } \\
\hline Theoretical $\chi^{2}$ value & 5.99 & 3.84 & 3.84 & 3.84 \\
\hline Test statistic & 6.20 & 0.30 & 4.98 & 1.89 \\
\hline$P$ value & $<0.05$ & 0.58 & $<0.05$ & 0.17 \\
\hline
\end{tabular}

BSA, body surface area; CRP, C reactive protein; CS, corticosteroid; DAS, Disease Activity Score; HAQ-DI, Health Assessment Questionnaire Disability Index; MTX, methotrexate; NSAID, non-steroidal anti-inflammatory drug; PASI, Psoriasis Area Severity Index; PsA, psoriatic arthritis; SJC, swollen joint count; TJC, tender joint count; TNF, tumour necrosis factor; TSS, Total Sharp Score; VAS, Visual Analogue Scale.

In period 2, the percentage of patients with dactylitis was the lowest $(30.1 \%)$; this was significantly higher in period $1(43.4 \%)$ and period $3(44.4 \%)$. The difference between periods 1 and 3 was too small to be significant. Patients with dactylitis were included when at least one digit was affected. The presence of enthesitis was low in period $1(33.9 \%)$ and significantly higher in period $2(67.1 \%)$ and period $3(65.8 \%)$. There were no data available for dactylitis or enthesitis in the etanercept and adalimumab studies which left 304 patients in period 1.

The number of patients with a psoriatic BSA of more or equal to $3 \%$ of their body surface was significantly higher in period $2(67.3 \%)$ than in period $1(60.7 \%)$ and period $3(58.5 \%)$. The difference between periods 1 and 3 was not significant. Data for the psoriatic BSA were missing in one of the etanercept and one of the infliximab studies, so there were 573 patients instead of 882 included in period 1 .

\section{Disease activity}

The SJC and TJC were significantly lower in period 2 (respectively $-2.42 \%, 95 \%$ CI -3.64 to -1.20 and $-2.79 \%$, $95 \%$ CI -4.81 to -0.77 ) and in period 3 (respectively $-1.66 \%, 95 \%$ CI -2.75 to -0.57 and $-1.13 \%, 95 \%$ CI -2.94 to -0.68 ) than in period 1 . The difference between periods 2 and 3 was not significant. For the SJC and the TJC, we made no difference between respectively the $0-66$ and the $0-76$ count for the SJC and the 0-68 and the $0-78$ count for the TJC, nor a statistical correction. We considered for both parameters 617 patients in period 1 and 1507 patients in period 3 due to missing data or other form of representation for etanercept and ustekinumab.

The CRP level was significantly different for all three periods with the lowest mean values in period $3(9.47$ $\mathrm{mg} / \mathrm{L})$ and the highest in period $1(18.36 \mathrm{mg} / \mathrm{L})$. The mean CRP level and SD were calculated for 617 patients in period 1 (infliximab and adalimumab), 405 patients in period 2 (golimumab) and 504 patients in period 3 (apremilast).

Disease activity estimated by the physician was significantly lower in period 1 than in period $2(+0.3 \mathrm{~cm}, 95 \%$ CI 0.02 to 0.58$)$. There was no statistically significant difference between periods 1 and 3 nor between periods 2 and 3 . Disease activity estimated by the patient was the lowest in period 1 and was significantly lower than in period 2
$(+0.75 \mathrm{~cm}, 95 \%$ CI 0.42 to 1.08$)$ and $3(+0.55 \mathrm{~cm}, 95 \%$ CI 0.31 to 0.79 ). There was no significant difference in mean VAS scores between periods 2 and 3. The patient's global assessment of pain measured by VAS was significantly different for all three periods with the lowest mean scores in period $1(5.32 \mathrm{~cm})$ and the highest in period 2 $(6.03 \mathrm{~cm})$. Physician's global assessment scores of disease activity were missing for the etanercept studies and three patients in the adalimumab study, so only 614 patients instead of 882 were considered. In period 2, there were no data available for golimumab. Ustekinumab had no data available for this parameter, which left 1507 patients in period 3. Patient's global assessment scores of disease activity and pain were missing for the etanercept studies and one patient in the adalimumab study, so only 616 patients instead of 882 were considered. In period 2, there were no data available for golimumab. Ustekinumab had no data available for these parameters, which left 1507 patients in period 3 .

DAS scores were significantly different for all three periods with the lowest mean values in period 2 (4.34) and the highest mean values in period 1 (5.45). We made no distinction between the DAS and the DAS28-CRP (which is assessed with the CRP level in 28 joints). In period 1 , there were only data for this parameter in one of the infliximab studies and thus for 104 patients. There were no data available for certolizumab in period 2 nor for ustekinumab in period 3 .

The PASI score was significantly higher in period 3 when compared with period $1(+2.57 \%, 95 \%$ CI 0.98 to $4.16)$ and period $2(+2.14 \%, 95 \%$ CI 0.52 to 3.76$)$. The PASI score was only evaluated for those patients with BSA $\geq 3 \%$. This left 308 patients in period 1, 296 patients in period 2 and 744 patients in period 3 .

\section{Disease effects}

We made no distinction between the TSS and the modified TSS in our evaluation. Statistical analysis of the TSS showed no significant difference between the three periods. There were no (complete) data available for the etanercept and infliximab studies and for two patients in the adalimumab study, so the mean TSS and SD were calculated for 311 patients in period 1. In period 2, there were no data for golimumab and in period 3 there were only data for one secukinumab study (606 patients). 
Quality of life assessed by the HAQ-DI score worsened significantly in period $2(+0.24 \%, 95 \%$ CI 0.14 to 0.34$)$ and $3(+0.16 \%, 95 \%$ CI 0.08 to 0.24$)$ when compared with the scores in period 1 . The slight improvement of quality of life for the patients in period 3 compared with period 2 was not significant. The HAQ-DI score was calculated for 617 patients in period 1 (infliximab and adalimumab), 409 patients in period 2 (certolizumab) and 1507 patients in period 3 (secukinumab and apremilast).

\section{Prior treatments}

As mentioned above, there were no data available concerning prior anti-TNF therapy in any of the studies in period 1; however, there is a significant difference in use of prior anti-TNF therapy between patients in period $2(19.6 \%)$ and period $3(28.9 \%)$. The number of patients with baseline use of MTX was significantly lower in period $1(46.7 \%)$ than in periods $2(55.8 \%)$ and $3(52.5 \%)$. There was no significant difference in MTX use between periods 2 and 3. For baseline use of MTX, there are only data missing for one infliximab study (778 instead of 882 patients in period 1).

No statistically significant difference was shown between the three periods in baseline use of oral GC. The baseline use of NSAIDs was only significantly lower in period $3(72.5 \%)$ when compared with period $1(77.9 \%)$. No significant difference was shown between the other two pairs of periods. Baseline use of oral GC was calculated for 465 patients in period 1 due to missing data for one of the infliximab studies and the adalimumab study and for 405 patients in period 2 due to missing data for certolizumab. Baseline use of NSAIDs was calculated for 465 patients in period 1 due to missing data for one of the infliximab studies and the adalimumab study, for 405 patients in period 2 due to missing data for certolizumab and for 1431 patients in period 3 due to missing data for secukinumab.

\section{DISCUSSION}

Our detailed analysis of the baseline characteristics of the patients with psoriatic arthritis that were included in pivotal clinical trials showed some remarkable differences between the three different treatment periods with most data indicating that these shifts have occurred between the first and the second period. In comparison with the initial trials with etanercept, infliximab and adalimumab, gender and race show more diversity, patients are older but have a shorter disease duration, show lower SJC and TJC, but more enthesitis, and have lower CRP levels. Although several of these parameters suggest an overall lower disease activity in the second and third period of trials, this is not reflected in the physician's and patient's perspective of disease activity and the HAQ-DI score.

The approach presented has a number of limitations such as selection of the trials, differences in inclusion criteria and the fact that our quantitative analysis was dependent on the reported data. However, overall, our analysis appears to suggest that the threshold to consider a patient with PsA for an advanced intervention has been lowered since the introduction of the drugs. This could be explained by the clear success of such strategies and the fact that initial safety concerns have been largely attenuated based on experience in clinical practice. Hence, older patients, patients with less disease activity but with considerable impact are now clearly considered candidates for advanced treatments.

The small shift towards an equal gender balance is of interest. In the general population, there is no sex difference in the prevalence of PsA. Some studies in the past have suggested male or female preponderance, but those findings were found in small study populations and were not consistent. ${ }^{7}$ In our analysis of the clinical trials, we see a male:female ratio nearly equal to $1: 1$ in period 3 whereas in period 1 there was a male preponderance in the study population. The trials performed in period 3 therefore give a better representation of the general population in terms of gender distribution.

Different factors than perception of effectiveness and safety may have contributed to the age shift. The efficacy of biologicals may be lost over time due to issues of tolerability, safety or development of immunogenicity. ${ }^{8}$ This could lead to the inclusion of an older study population in the third period as patients with prior anti-TNF exposure could be included.

Even though there were more non-Caucasian patients included in the latest period of drug trials, the percentage of non-Caucasians in the study populations is strikingly low. This is somewhat consistent with the low prevalence of PsA in Asians and Africans or African Americans. ${ }^{1}$ A review of prevalence of arthritis in Africa showed a serious lack of data of patients with arthritis in Africa. One population-based study from urban South Africa found a prevalence of PsA of $4.4 \%$. Further data collection from patients in Africa is needed. ${ }^{9}$

PsA is associated with obesity which can be seen by the high mean weight values in the different periods of the clinical trials. ${ }^{1}$ Regardless of the increased prevalence of overweight and obesity in the general population, there has not been a significant change of mean weight in our analysis.

Attention towards dactylitis and enthesitis has been limited in the first period of trials but has since then clearly increased. The presence of dactylitis in periods 1 and 3 is consistent with the prevalence of dactylitis in the general PsA patient population. The presence of dactylitis is important to observe because of its association with severe disease. In our analysis, we found prevalences of enthesitis of $33.9 \%$ in period 1 and up to $67.1 \%$ in period 2 and $65.8 \%$ in period 3. Increased attention towards the role of enthesitis as a disease-specific and disease-triggering mechanism as well as the now well-established use of enthesitis scores may have contributed to the increased recognition and inclusion of these patients. ${ }^{1}$

The disease activity parameters (TJC, SJC, CRP level, DAS) showed less active disease in the later periods 
than in period 1. As a limitation, our analysis made no distinction nor a statistical correction between DAS and DAS28-CRP neither between the different joint counts (0-66 and 0-76 for the SJC and 0-68 and 0-78 for the TJC). The PASI score is higher in the third period than in the first and the second. Factors such as the inclusion of anti-TNF failures and the inclusion of patients with less severe joint but more severe skin disease may have contributed to this observation.

Patients showed poorer health-related quality of life in the second and the third periods compared with the first period despite the observation that other disease parameters suggested less severe disease. Nonetheless the better disease control and the progress in treatment possibilities, the psychosocial burden of PsA should not be underestimated and depends on several components (body image, psychological factors, personality, cognition and attention to pain, sleep and fatigue, depression and mood/behavioural changes, occupation/work productivity). It is an interesting question to study the evolution of these factors in time and to evaluate their influence on overall quality of life. A key point in patient satisfaction appears to be receiving clear information about treatment, diagnosis or how to improve daily activities. This shows the importance of an interdisciplinary team in the care of patients with PsA. ${ }^{10}$ Interestingly, in patients with PsA, subjective disease activity evaluations by physicians in daily clinical practice do not appear to match with predefined activity measures or patient-reported outcomes, further highlighting the impact of subjective physician-linked factors in daily decision-making. ${ }^{11}$ Another aspect that will deserve future attention is the raise in placebo responses in newer trials. The factors that explain this observation remain unclear but perceived impact of the disease at baseline and eligibility creep at inclusion may play a role in this. ${ }^{12}$

\section{CONCLUSION}

Our analysis found significant differences in patient characteristics, disease characteristics, disease activity, disease effects and use of prior treatments between the three periods of treatment drugs since the introduction of biologicals. Patients appear to be considered earlier and with less severe disease although the subjective evaluation of disease activity goes in the opposite direction. Further research is needed to see if the changes apparent in clinical trial populations can also be observed in the daily clinical practice. Also, our data may warn against direct comparisons of clinical trial data originating from different time periods.

Acknowledgements The data in this paper were previously presented as an abstract at the European League against Rheumatism congress 2018 in Amsterdam (25)

Contributors RL and KdV designed the study. A-SV collected the data and performed the analyses. A-SV and RL wrote the manuscript. KdV commented and contributed to the manuscript.

Funding Clinical research on psoriatic arthritis at University Hospitals Leuven is currently supported by kind donations from Carpe Diem II.
Competing interests Leuven Research and Development, the technology transfer office of KU Leuven has received speaker's and consultancy fees on behalf of RL from Abbvie, Boehringer-Ingelheim, Celgene, Eli-Lilly, Janssen, Novartis, Merck, Pfizer and UCB, and research grants from Boehringer-Ingelheim, Celgene and Pfizer. KdV reports speaker's and consultancy fees from Abbvie, Celgene, Eli-Lilly, Johnson \& Johnson, Merck, Novartis, Pfizer and UCB.

Patient consent for publication Not required.

Provenance and peer review Not commissioned; externally peer reviewed.

Data sharing statement All data are present in the paper. No additional data are available.

Open access This is an open access article distributed in accordance with the Creative Commons Attribution Non Commercial (CC BY-NC 4.0) license, which permits others to distribute, remix, adapt, build upon this work non-commercially, and license their derivative works on different terms, provided the original work is properly cited, appropriate credit is given, any changes made indicated, and the use is non-commercial. See: http://creativecommons.org/licenses/by-nc/4.0/.

\section{REFERENCES}

1. Ritchlin CT, Colbert RA, Gladman DD. Psoriatic arthritis. N Engl J Med 2017;376:957-70.

2. Coates LC, Helliwell PS. Psoriatic arthritis: state of the art review. Clin Med 2017;17:65-70.

3. Caso F, Del Puente A, Peluso R, et al. Emerging drugs for psoriatic arthritis. Expert Opin Emerg Drugs 2016;21:69-79.

4. Costa L, Del Puente A, Peluso R, et al. Small molecule therapy for managing moderate to severe psoriatic arthritis. Expert Opin Pharmacother 2017;18:1557-67.

5. Ogdie A, Coates L. The changing face of clinical trials in psoriatic arthritis. Curr Rheumatol Rep 2017;19:21.

6. Schett G, Wollenhaupt J, Papp K, et al. Oral apremilast in the treatment of active psoriatic arthritis: results of a multicenter, randomized, double-blind, placebo-controlled study. Arthritis Rheum 2012;64:3156-67.

7. Andersen LK, Davis MD. Sex differences in the incidence of skin and skin-related diseases in Olmsted County, Minnesota, United States, and a comparison with other rates published worldwide. Int J Dermatol 2016;55:939-55.

8. Hawkes JE, Chan TC, Krueger JG. Psoriasis pathogenesis and the development of novel targeted immune therapies. J Allergy Clin Immunol 2017;140:645-53.

9. Usenbo A, Kramer V, Young T, et al. Prevalence of arthritis in Africa: a systematic review and meta-analysis. PLoS One 2015;10:e0133858.

10. Husni ME, Merola JF, Davin S. The psychosocial burden of psoriatic arthritis. Semin Arthritis Rheum 2017;47:351-60.

11. van Mens LJJ, Turina MC, van de Sande MGH, et al. Residual disease activity in psoriatic arthritis: discordance between the rheumatologist's opinion and minimal disease activity measurement. Rheumatology 2018;57:283-90.

12. Hick J, Feldman SR. Eligibility creep: a cause for placebo group improvement in controlled trials of psoriasis treatments. J Am Acad Dermatol 2007;57:972-6.

13. Mease PJ, Goffe BS, Metz J, et al. Etanercept in the treatment of psoriatic arthritis and psoriasis: a randomised trial. Lancet 2000;356:385-90.

14. Mease PJ, Kivitz AJ, Burch FX, et al. Etanercept treatment of psoriatic arthritis: safety, efficacy, and effect on disease progression. Arthritis Rheum 2004;50:2264-72.

15. Antoni CE, Kavanaugh A, Kirkham B, et al. Sustained benefits of infliximab therapy for dermatologic and articular manifestations of psoriatic arthritis: results from the infliximab multinational psoriatic arthritis controlled trial (IMPACT). Arthritis Rheum 2005;52:1227-36.

16. Antoni C, Krueger GG, de Vlam K, et al. Infliximab improves signs and symptoms of psoriatic arthritis: results of the impact 2 trial. Ann Rheum Dis 2005;64:1150-7.

17. Mease PJ, Gladman DD, Ritchlin CT, et al. Adalimumab for the treatment of patients with moderately to severely active psoriatic arthritis: results of a double-blind, randomized, placebo-controlled trial. Arthritis Rheum 2005;52:3279-89.

18. Kavanaugh A, Mclnnes I, Mease P, et al. Golimumab, a new human tumor necrosis factor alpha antibody, administered every four weeks as a subcutaneous injection in psoriatic arthritis: twenty-four-week efficacy and safety results of a randomized, placebo-controlled study. Arthritis Rheum 2009;60:976-86

19. Mease PJ, Fleischmann R, Deodhar AA, et al. Effect of certolizumab pegol on signs and symptoms in patients with 
psoriatic arthritis: 24-week results of a phase 3 double-blind randomised placebo-controlled study (RAPID-PsA). Ann Rheum Dis 2014;73:48-55.

20. Mclnnes IB, Kavanaugh A, Gottlieb AB, et al. Efficacy and safety of ustekinumab in patients with active psoriatic arthritis: 1 year results of the phase 3 , multicentre, double-blind, placebo-controlled PSUMMIT 1 trial. Lancet 2013;382:780-9.

21. Ritchlin C, Rahman P, Kavanaugh A, et al. Efficacy and safety of the anti-IL-12/23 p40 monoclonal antibody, ustekinumab, in patients with active psoriatic arthritis despite conventional non-biological and biological anti-tumour necrosis factor therapy: 6-month and 1 -year results of the phase 3 , multicentre, double-blind, placebo-controlled, randomised PSUMMIT 2 trial. Ann Rheum Dis 2014;73:990-9.
22. Mease PJ, Mclnnes IB, Kirkham B, et al. Secukinumab inhibition of interleukin-17A in patients with psoriatic arthritis. N Engl J Med 2015;373:1329-39.

23. Mclnnes IB, Mease PJ, Kirkham B, et al. Secukinumab, a human anti-interleukin-17A monoclonal antibody, in patients with psoriatic arthritis (future 2): a randomised, double-blind, placebo-controlled, phase 3 trial. Lancet 2015;386:1137-46.

24. Kavanaugh A, Mease PJ, Gomez-Reino JJ, et al. Treatment of psoriatic arthritis in a phase 3 randomised, placebo-controlled trial with apremilast, an oral phosphodiesterase 4 inhibitor. Ann Rheum Dis 2014;73:1020-6.

25. Vandendorpe AS, De Vlam K, Lories R. OP0311 Notable evolutions in the characteristics of psoriatic arthritis clinical trials populations in the era of biological treatments. Ann Rheum Dis 2018;77(S2):202-3. 